\title{
Review
}

\section{A tirania dos poderes coniventes: $O$ Brasil na conjuntura}

\author{
Diogo Sardinha \\ Contracorrente, São Paulo, 2019, 128 pp., \\ ISBN: 978-85-69220-67-1
}

Contemporary Political Theory (2021) 20, S78-S81. https://doi.org/10.1057/s41296020-00396-3; published online 21 April 2020

Diogo Sardinha is a renowned Portuguese philosopher who has written extensively on Immanuel Kant, Gilles Deleuze, and Michel Foucault. He also has the distinction of having been the only non-French President of the Collège International de Philosophie in Paris. Sardinha's new book A tirania dos poderes coniventes: O Brasil na conjuntura (The Tyranny of Conniving Powers: Brazil in the Conjuncture) brings his philosophical acumen to bear on the current political situation in Brazil. It contributes to a growing list of books about the decline of the center-left Workers' Party (PT) and the ascendance of the far-right forces that culminated in the victory of Jair Bolsonaro in the presidential election of 2018.

One already obvious tendency in this literature is to focus on the missteps of the long-governing PT as a major reason for the rise of Bolsonaro. Perry Anderson, for example, charts this course in Brazil Apart: 1964-2019. He suggests that the actions and inactions of the successive governments of the PT laid the groundwork for the victory of Bolsonaro. Sardinha also focuses on the PT but he differs from Anderson in concentrating on its policies in order to formulate a set of questions that probe the more enduring structures of Brazilian society.

Sardinha asks what was so unsettling in these policies to the traditional ordering of Brazilian society. Why did they touch a raw nerve among the elites in Brazilian society? Sardinha's core argument is that the PT ultimately produced a fierce backlash because it succeeded in subtly diminishing the gaps between the poles of privilege and disadvantage in Brazilian society. He is far too uncritical of the PT in the elaboration his argument but the breadth of his undertaking compensates for this shortcoming. Sardinha asks big questions that get at the core of the ordering of Brazilian society and his conceptually rich answer to these questions has implications that extend beyond Brazil.

Bolsonaro's victory was premised on what Sardinha aptly describes as 'the definitive banishment from social and political life' (p. 54) of a formidable contender to the presidency. That contender was, of course, the former president of

(c) 2020 Springer Nature Limited. 1470-8914 Contemporary Political Theory Vol. 20, S2, S78-S81 
Brazil and leader of the PT, Luiz Inácio Lula da Silva. Sardinha reminds us that Lula was not just imprisoned until his release in November 2019. He was also prohibited from running as a presidential candidate, voting, and even giving interviews to the press from prison. For Sardinha, the magistrates who banished Lula succeeded in destroying the semblance of democracy in Brazil that the PT had nourished during its years in power. These magistrates were not alone in this achievement. Members of congress, the media, business leaders, street protestors, and the military participated in frenzied calls for the banishment of Lula.

To help us understand this turn of events, Sardinha offers his own unique conceptual twist on a problem he acknowledges others have posed and resolved. That problem concerns the glaring difference between the aversion of the PT to immediately antagonize Brazilian elites as well as the remarkable wealth that these elites had accrued under PT governments, on the one hand, and the upsurge of raw hatred toward the PT in general and Lula in particular among the elites only a few years later, on the other hand. Why did the governments of the PT generate so much hatred among those who benefited materially from their policies? Why did the PT as well as Lula and his successor Dilma Rousseff provoke such an outpouring of hatred?

There is one easy answer to these questions: outrage over corruption scandals involving Lula and other PT leaders. Sardinha, however, downplays the importance of this answer. He insists that Lula at least was condemned without any proof of his involvement in corruption. Sardinha also treats the much-heralded fight against corruption as a cover for the deeper political ambitions of the former federal judge and current Minister of Justice and Public Security Sérgio Moro. He finds the stark and scandalous proof of these ambitions in Moro's actions in the immediate aftermath of the presidential election. Moro revealed his own political preferences and ambitions by suddenly accepting his ministerial position from Bolsonaro after having facilitated the very conditions for the victory of Bolsonaro through the persecution of Lula.

In contrast to the dominant narrative, Sardinha's own explanation of the elites' hatred of the PT and its representatives springs from his rich formulation of the concept of anthropological differences. This concept is intended to capture historically and geographically modifiable distinctions that 'define the possible, always precarious stability of a human group and the relations within it' (p. 55). Put more concretely, anthropological differences encompass distinctions in 'class, color, sex, gender, territoriality, mobility, and status' (p. 55). What defines each category of distinction is not a binary opposition so much as a continuum for the placement of individuals between two extremes. Such extremes include the 'rich and poor (class difference), black and white (color), man and woman (sex), heterosexual and homosexual (gender), center and periphery (territoriality), colonizer and indigenous (mobility), and with and without public power (legal standing)' (pp. 55-56). Taken together, these extremes define the differences that

(C) 2020 Springer Nature Limited. 1470-8914 Contemporary Political Theory Vol. 20, S2, S78-S81 
accumulate and crystallize into poles of privilege and disadvantage in any given society. To give some flesh to this point, Sardinha claims that in Brazil the 'richwhite-urban-man-descended from colonizers' (p. 58) marks out a pole of privilege while the 'poor-black-peripheral-woman-descended from slaves' (p. 58) distinguishes a pole of disadvantage.

Sardinha contends that the PT engaged in a diminution of the anthropological differences that organize social status in a remarkably short period of time. The pursuit of this swift diminution stood in contrast to a more traditional strategy on the left of property expropriation. Sardinha maintains that the PT did not pursue that strategy because it feared an immediate backlash from the wealthy. It settled instead on a strategy of more subtly working to diminish anthropological differences through another kind of expropriation, namely the expropriation of the enormous privileges accumulated through these differences. This strategy had the immediate advantage of producing a delay in the response of the elites for three reasons: first, it was not as sharply felt as the outright expropriation of property would have been; second, the tremendous wealth these elites accumulated under PT governments 'compensated' (p. 58) for the reduction of anthropological differences; finally, the expropriations of these governments were symbolic rather than material.

Sardinha's most vivid and compelling illustration of the expropriation of privileges comes from the PT's introduction of social protections for housemaids, which 'put a stop' (p. 61) to forms of subjection that took place in the otherwise obscure space of the family as a locus of patriarchal reproduction. In other words, the PT instituted 'an apparently anodyne legal measure' (p. 61) that had the effect of intervening in the family to strip its members of the longstanding privilege of mistreating and abusing housemaids. The result of this intervention was nothing less than a 'slow motion' (p. 62) groundswell of hatred and resentment among family members who had lost that privilege. As Sardinha points out, these members began to clamor on the streets (with their nannies in tow) for a return to an order 'in which a housemaid was little or nothing more than an appendage of the patriarchal family structure' (p. 62).

Sardinha takes the sheer force of such reactions as proof that the PT had in fact disturbed something fundamental in the traditional ordering of Brazilian society. Indeed, he insists that only such a disturbance can account for the intensity of the hatred toward the PT as well as the very persons of Lula and Rousseff. The ascendance to the presidency of a union leader without higher education (Lula), followed by a woman who had been tortured under the dictatorship (Rousseff), unleashed this hatred by symbolically unsettling the supposedly " "natural order of things", (p. 112) in Brazil.

Sardinha acknowledges that the PT committed 'errors' (p. 65) but he is elusive about the content of these errors and deflects from them by asking instead how the PT could not have committed mistakes over its long years in power. Sardinha's 
insistence that the PT fostered the 'appearance' (p. 19) of democracy in Brazil certainly seems like a critical observation but it actually comes across as a kind of praise, since he proceeds to concentrate on how the judiciary destroyed even that appearance. Even though Sardinha hesitantly recognizes that the PT enacted policies that made the wealthy wealthier, he construes such policies as the price it had to pay for reducing anthropological differences. Sardinha also does not ask what seems like an obvious question given his conceptualization of these differences: is it possible that the PT could have fortified, rather than simply diminished, anthropological differences through its compromises with the elites?

Still, it easy to put aside Sardinha's tepidly critical attitude toward the PT because there is much to admire in his analysis. Sardinha's new book is more than just timely. It elaborates a concept of anthropological differences with an import beyond Brazil. This concept delineates the complex poles of disadvantage and privilege that can serve as objects of intervention for governments aspiring to reduce inequalities. Sardinha also offers a cautionary tale to such governments, namely that there is an enormous price to pay for the realization of such aspirations. That price comes in the form of an unleashing of the forces of anger, hatred, resentment, and vengeance. In Sardinha's haunting expression, disturbing anthropological differences is like 'playing with fire' (p. 111).

Publisher's Note Springer Nature remains neutral with regard to jurisdictional claims in published maps and institutional affiliations.

Marcelo Hoffman

Jersey City, NJ 07302, USA marceloihoffman@gmail.com 